\title{
Journal of Diabetic Complications \&
}

\section{Frequency of Hypertension in Diabetes Patient in District Dera Ghazi Khan}

\section{Ayaz Ahmad}

Biology Governament Degree College, Punjab, Pakistan

${ }^{*}$ Corresponding author: Ayaz Ahmad, Assistant Professor, Biology Government Degree College, Punjab, Pakistan, Tel: +923346789348; E-mail: ayaz_sarkani@yahoo.com

Received date: April 2, 2018; Accepted date: April 04, 2018; Published date: April 13, 2018

Copyright: ( 2018 Ahmad A. This is an open-access article distributed under the terms of the Creative Commons Attribution License, which permits unrestricted use, distribution, and reproduction in any medium, provided the original author and source are credited.

\section{Retraction Note:}

The article entitled "Frequency of Hypertension in Diabetes Patient in District Dera Ghazi Khan" has been accepted for publication in the Journal of Diabetic Complications and Medicine the article by Ayaz Ahmad. The retraction is due to lack of experimental evidences. 